\title{
PELATIHAN FISIK SEDANG MENINGKATKAN KADAR VASCULAR ENDOTHELIAL GROWTH FACTOR DAN STROMAL CELL-DERIVED FACTOR-1 SERUM
}

\section{Moderate Physical Exercise Increases Serum Vascular Endothelial Growth Factor and Stromal Cell-Derived Factor-1 Level}

\author{
Anak Agung Ayu Putri Permatasari, I Wayan Rosiana, I Gede Widhiantara, \\ Chela Krisna Denata, Ferbian Milas Siswanto*
}

Program Studi Biologi, Fakultas Ilmu Kesehatan Sains dan Teknologi, Universitas Dhyana Pura Jln Raya Padangluwih, Dalung, Kuta Utara, Badung, Bali 80361, Indonesia *Email: ferbianms@undhirabali.ac.id

\begin{abstract}
Physical exercise affects many systems in the body that play a role in maintaining physical fitness and slowing down the aging process. This study aimed to identity VEGF and SDF-1 as the mechanism of exercise-related anti-aging therapy. This study was a randomized pretestposttest control group design study, using 24 Wistar rats (Rattus norvegicus), male, 2.5-3 months old, weighing 180-200 g, and healthy. Rats were divided into two groups $(n=12)$. The control group was a sedentary lifestyle-treated group $(P 0)$ and the treatment group was subjected to moderate physical exercise for 4 weeks (P1). Both VEGF and SDF-1 levels were examined using the ELISA method. The results showed that moderate physical exercise increased VEGF $\left(43.88 \pm 6.24\right.$ to $\left.69.80 \pm 10.04 \mathrm{pg} \mathrm{mL}^{-1} ; p<0.001\right)$ and SDF-1 (1.82 \pm 0.17 to $3.81 \pm 0.39 \mathrm{ng} \mathrm{mL}^{-1} ; p<0.001$ ) levels significantly. This study, therefore, suggested the possibility of VEGF and SDF-1 as a mediator of moderate physical exercise-induced anti-aging effect.
\end{abstract}

Keywords: aging, exercise, rats, SDF-1, VEGF

\begin{abstract}
ABSTRAK
Pelatihan fisik mempengaruhi berbagai sistem dalam tubuh yang berperan mempertahankan kebugaran fisik dan memperlambat proses penuaan. Penelitian menunjukkan bahwa kadar vascular endothelial growth factor (VEGF) dan stromal cell-derived factor-1 (SDF-1) menurun seiring dengan penuaan. Penelitian ini bertujuan membuktikan bahwa pelatihan fisik sedang meningkatkan kadar VEGF dan SDF-1 sebagai salah satu mekanisme penghambat proses penuaan. Penelitian ini menggunakan randomized pre-post test control group design dengan menggunakan 24 ekor tikus wistar (Rattus norvegicus) jantan sehat dengan umur 2,5 - 3 bulan, berat badan 180 -200 g yang dibagi dalam dua kelompok ( $\mathrm{n}=12$ ekor). Kelompok kontrol tidak diberikan perlakuan atau sedentary lifestyle (P0) dan kelompok perlakuan diberi pelatihan fisik sedang selama 4 minggu (P1). Kadar VEGF dan SDF-1 diperiksa menggunakan ELISA. Hasil penelitian menunjukkan bahwa pelatihan fisik sedang meningkatkan kadar VEGF $(43,88 \pm 6,24$ menjadi $\left.69,80 \pm 10,04 \mathrm{pg} \mathrm{mL}^{-1} ; p<0,001\right)$ dan SDF-1 $\left(1,82 \pm 0,17\right.$ to $\left.3,81 \pm 0,39 \mathrm{ng} \mathrm{mL}^{-1} ; \mathrm{p}<0,001\right)$. Hasil penelitian ini menunjukkan kemungkinan VEGF dan SDF-1 sebagai mediator efek yang memperlambat penuaan. Namun, perlu dilakukan penelitian lebih lanjut untuk mengidentifikasi korelasi antara peningkatan kadar VEGF dan SDF-1 dengan fenotip penuaan.
\end{abstract}

Kata Kunci: pelatihan fisik, penuaan, SDF-1, tikus, VEGF 


\section{PENDAHULUAN}

Pelatihan fisik merupakan hal yang sangat penting bagi kehidupan manusia, hal ini karena pelatihan fisik telah dikaitkan dengan kebugaran fisik. Kondisi lingkungan yang tepat serta dosis pelatihan yang diatur dengan baik sangat mendukung untuk mendapatkan hasil yang maksimal dan resiko yang minimal. Pelatihan fisik yang seimbang sesuai dengan kaidah fisiologi olahraga akan mampu mempertahankan kebugaran fisik dan mencegah peroses penuaan (Siswanto dan Pangkahila 2014, Siswanto dan Pangkahila 2015).

Pelatihan fisik yang baik sebagai upaya untuk mencegah penuaan adalah yang sesusi dengan kaidah frequency, intensity, time dan type (FITT). Prinsip pelatihan fisik seimbang antara lain: (1) Tubuh harus dalam keadaan sehat; (2) Sebelum melakukan aktivitas fisik harus dilakukan pemeriksaan denyut nadi istirahat; (3) Dilakukan pemanasan (warming up) selama 5 menit untuk meningkatkan denyut nadi minimal 30 denyut dari denyut nadi istirahat; (4) Frekuensi (frequency) latihan $(F)$ : Frekuensi latihan 3 - 6 kali perminggu, tidak boleh istirahat lebih daripada 48 jam agar kebugaran fisik selalu siap. Frekuensi 6 kali perminggu dua kali lebih efektif dibandingkan 3 kali perminggu. (5) Intensitas (intensity) latihan (I): Intensitas latihan berpedoman pada $(65-85 \%)$ x Denyut Nadi Maksimal (DNM); (6) Waktu (time) latihan (T): Waktu 30 - 60 menit setiap hari dan tipe latihan sesuaikan dengan kondisi tubuh; (7) Tipe (type) latihan (T): Tipe latihan yang sesuai dengan kondisi dan situasi pribadi seseorang memang tidak terlalu mudah sebab sebagian orang melakukan latihan yang disenangi tetapi tidak sesuai dengan kondisi tubuhnya (Siswanto dan Pangkahila 2015).

Pelatihan fisik yang seimbang dipercaya dapat mencegah penuaan dan justru memperpanjang masa hidup. Penelitian menunjukkan bahwa pelatihan fisik seimbang meningkatkan kapasitas antioksidan endogen tanpa menginduksi kerusakan jaringan (Kartiko dan Siswanto 2018). Selain itu, pelatihan fisik yang seimbang dapat meningkatkan mobilisasi stem cell yang dapat berperan sebagai progenitor pada reparasi jaringan yang rusak (Siswanto dan Pangkahila 2014, Zenitalia et al. 2018). Mekanisme lainnya yang terlibat dalam efek anti penuaan pelatihan fisik seimbang adalah dengan mempertahankan kadar hormon endorphin dan menurunkan kadar hormon kortisol, dimana kedua hormon ini memiliki efek antagonis dalam pengaturan penuaan akibat kondisi stress (Hill et al. 2008, Pangkahila et al. 2016). Pelatihan fisik seimbang juga berkaitan dengan peningkatan hormon seks (Hayes et al. 2017), mempertahankan fungsi sistem imun (Nieman dan Wentz 2019), dan berefek genetic melalui perpanjangan telomer (Arsenis et al. 2017).

Secara umum penuaan merupakan akumulasi dari banyak kegagalan dalam sistem tubuh, dan pelatihan fisik seimbang terbukti dapat mencegah kegagalan berbagai sistem tubuh melalui berbagai mekanisme. Penelitian belakangan ini menunjukkan bahwa kadar vascular endothelial growth factor (VEGF) menurun seiring dengan penuaan (Zara et al. 2013, Ahluwalia et al. 2014, Hohman et al. 2015). VEGF merupakan faktor angiogenik yang berperan penting sebagai faktor pertumbuhan sel endotel pembuluh darah (Siswanto et al. 2017). Kadar VEGF yang rendah pada orang yang tua berkaitan dengan penyakit Alzheimer (Hohman et al. 2015) dan aged macular degeneration (AMD) (Luo et al. 2013). Jika pelatihan fisik seimbang dapat mencegah proses penuaan dengan mempertahankan kadar hormon, meningkatkan respon antioksidan, mempertahankan fungsi imun, hingga memperpanjang telomer; maka terdapat kemungkinan bahwa pelatihan fisik seimbang juga dapat mencegah terjadinya penyakit penuaan seperti Alzheimer dan AMD melalui peningkatan VEGF.

Selain VEGF, penuaan juga belakangan ini dikaitkan dengan penurunan kadar stromal cell-derived factor-1 (SDF-1). SDF-1 merupakan anggota dari keluarga chemokine CXC pro-inflamasi, yang aktif ketika berikatan dengan reseptornya CXCL4 untuk mengatur berbagai proses fisiologis, termasuk perkembangan embrionik dan homeostasis organ (Ho et al. 2012). Penelitian menunjukan bahwa penuaan menginduksi zeste homolog 2 (EZH2) dan histone $\mathrm{H} 3$ lisin 27 trimetilasi pada promotor SDF-1 sehingga menurunkan ekspresi mRNA dari gen sdf-1 (Nishiguchi et al. 2018). 
Bersamaan dengan VEGF, SDF-1 merupakan faktor yang menginduksi mobilisasi stem cells sehingga berkaitan dengan kemampuan regenerasi tubuh untuk mencegah kondisi patologis dan proses penuaan (Bogoslovsky et al. 2011, Tang et al. 2011, Liu et al. 2012, Siswanto dan Pangkahila 2014, Herrmann et al. 2015).

Penelitian ini bertujuan untuk membuktikan bahwa pelatihan fisik dapat meningkatkan kadar VEGF dan SDF-1 sebagai salah satu patofisiologi menghambat proses penuaan.

\section{BAHAN DAN METODE}

\section{Alat dan bahan penelitian}

Alat yang digunakan adalah kandang tikus yang di dalamnya terdapat sekam dan botol minum, ember, timbangan digital, buku dan alat pencatat data, sarung tangan, masker, kapas, tabung Eppendorf, tabung EDTA. Bahan habis pakai yang digunakan antara lain makanan tikus berupa pellet dan air minum, ketamin $10 \%$, xylazine $2 \%$, alkohol $70 \%$.

\section{Prosedur penelitian}

Tikus yang digunakan dalam penelitian ini adalah tikus putih jantan galur Wistar yang berumur 2,5-3 bulan dengan berat 180-200 g (Gambar 1A). Semua tikus diadaptasikan terlebih dahulu selama 7 hari sebelum diberi perlakuan. Semua tikus wistar jantan muda dibagi 2 kelompok. Kelompok 1 sebagai

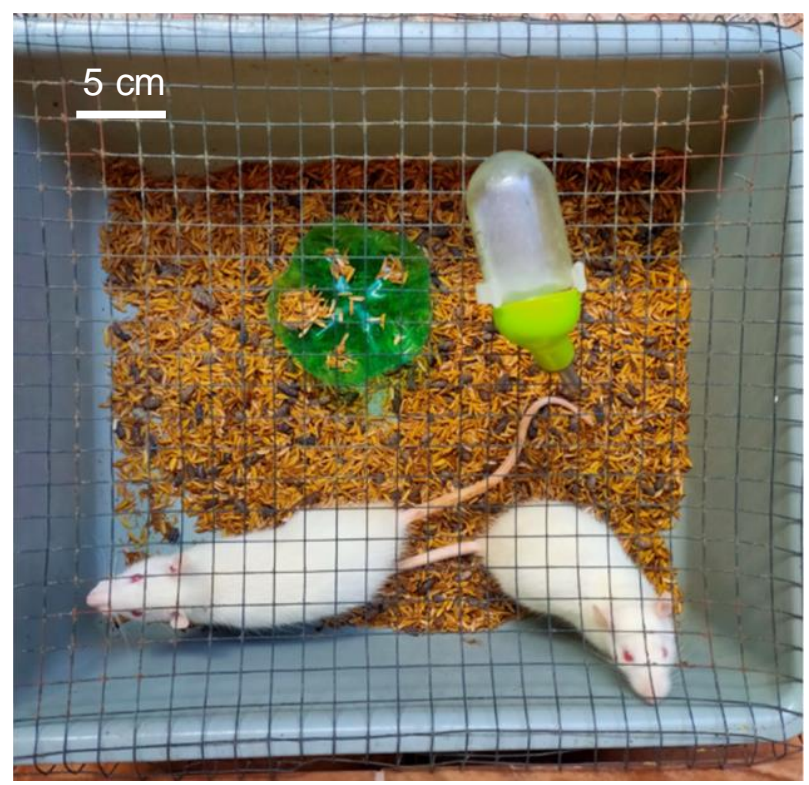

kelompok P0 yang tidak diberikan perlakuan. Kelompok 2 sebagai kelompok $\mathrm{P} 1$ yang diberi pelatihan fisik seimbang berupa renang selama \pm 45 menit dan dilakukan 3 kali seminggu selama 4 minggu (Gambar 1B). Sebelum dan setelah 4 minggu perlakuan, semua tikus pada kelompok 2 diperiksa berat badan dan diambil serum darahnya sebanyak $1 \mathrm{ml}$ melalui medial canthus sinus orbitalis, dengan sebelumnya dilakukan anestesi dengan ketamine $10 \%$ dosis $50 \mathrm{mg} \mathrm{kg}^{-1} \mathrm{BB}$ dan xylazine $2 \%$ dosis $20 \mathrm{mg} \mathrm{kg}^{-1} \mathrm{BB}$ disuntikkan intramuscular pada bagian paha tikus, darah yang diambil diperiksa kadar VEGF dan kadar SDF-1.

\section{Prosedur pemeriksaan kadar VEGF dan SDF-1}

VEGF dan SDF-1 yang terkandung dalam plasma akan terikat pada anti-rat VEGF dan SDF-1 monoclonal antibody yang telah dilapisi pada fase padat (sumuran). Sumuran kemudian dicuci dan ditambahkan biotinylated antibodi anti-rat VEGF atau antirat SDF-1. Sumuran kembali dicuci untuk membuang biotinylated antibody yang tidak terikat. Konjugat streptavidin-horse radish peroxidase (HRP) kemudian ditambahkan. Sumuran kembali dicuci dan ditambahkan larutan substrat 3,3',5,5'tetramethylbenzidine (TMB), menghasilkan warna biru yang sebanding dengan kadar VEGF dan SDF-1 dalam plasma. Stop solution mengubah warna biru menjadi kuning, dan intensitas warna diukur pada

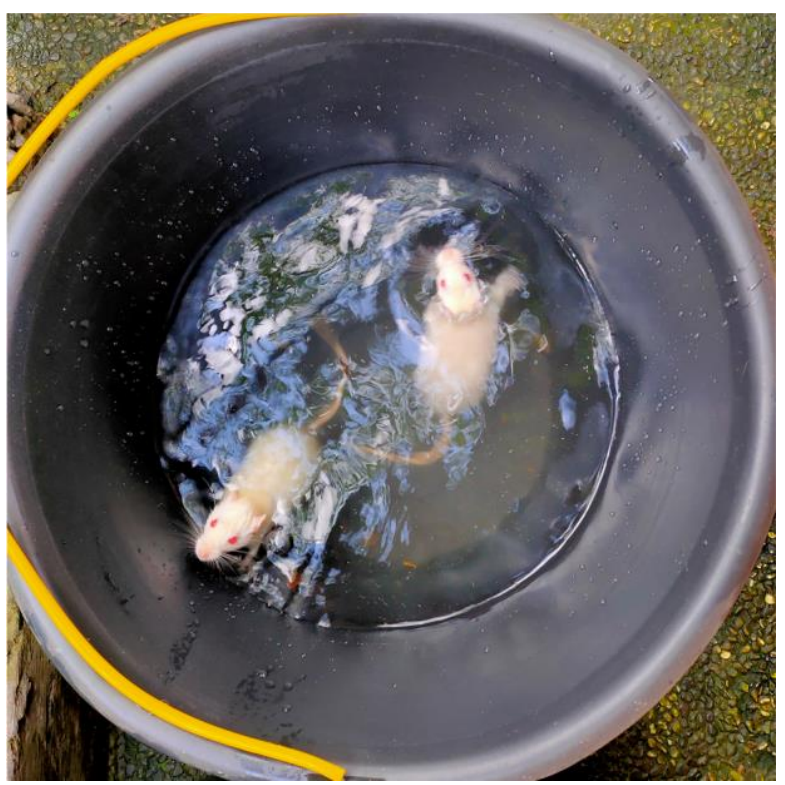

Gambar 1. Tikus (Rattus norvegicus) galur Wistar jantan yang digunakan sebagai subjek dalam penelitian ini. (A) tikus dalam kandang. (B) Perlakuan pelatihan fisik pada kelompok perlakuan (P1) 
Tabel 1. Berat Badan pada kelompok Kontrol (P0) dan kelompok perlakuan (P1), baik sebelum (pretest) dan sesudah (posttest) perlakuan

\begin{tabular}{lccc}
\hline \multirow{2}{*}{ Kelompok } & \multicolumn{2}{c}{ Berat Badan $(\mathrm{g})$} & \multirow{2}{*}{$p^{*}$} \\
\cline { 2 - 3 } & Pretest & Posttest & \\
\hline Kelompok P0 & $189,6 \pm 9,87$ & $188,3 \pm 7,12$ & 0,661 \\
Kelompok P1 & $185,4 \pm 6,39$ & $172,9 \pm 13,1$ & $<0,05$ \\
$p^{\star *}$ & 0,314 & $<0,05$ & \\
\hline
\end{tabular}

$p^{*}=$ paired $t$ test $; p^{* *}=$ independent $t$ test

panjang gelombang $450 \mathrm{~nm}$. Reagen yang dipakai adalah RayBio® Rat VEGF ELISA Kit (RayBiotech,Inc.) dan Rat SDF-1 ELISA kit (MyBioSource Inc., San Diego, CA, USA). Nilai pengukuran berskala rasio.

\section{Analisis data}

Data berat badan, kadar VEGF dan kadar SDF-1 dipresentasikan sebagai nilai rerata \pm simpangan baku (SB). Signifikansi antar kelompok pada waktu yang sama diuji menggunakan independent t-test. Signifikansi pretest-posttest dalam satu kelompok diuji menggunakan paired t-test. Perbedaan dianggap signifikan ketika $p<0,05$ $\left(^{*}\right)$ atau $p<0,01\left(^{* *}\right)$.

\section{HASIL DAN PEMBAHASAN}

\section{Efek pelatihan fisik terhadap berat badan}

Berat badan tikus sebelum dan sesudah perlakuan selama 4 minggu diperiksa. Hasil menunjukkan bahwa berat badan tikus kelompok Kontrol (P0) dan kelompok perlakuan (P1) sebelum perlakuan tidak berbeda bermakna $(p>0,05)$. Sesudah perlakuan, berat badan Kelompok P1 lebih rendah dibandingkan Kelompok P0 $(p<0,05)$ (Tabel 1).

\section{Efek pelatihan fisik terhadap VEGF}

Kadar VEGF diperiksa dengan menggunakan VEGF Elisa Kit for Rats. VEGF yang terkandung dalam serum darah akan terikat pada anti-rat VEGF monoclonal antibody yang telah dilapisi pada fase padat (sumuran). Hasil pemeriksaan kadar VEGF menunjukkan bahwa tidak terdapat perubahan kadar VEGF pada kelompok kontrol P0 $(p>0,05)$. Namun sebaliknya, kadar VEGF pada kelompok P1 meningkat setelah perlakuan selama 4 minggu
Tabel 2. Kadar VEGF pada kelompok Kontrol (P0) dan kelompok perlakuan (P1), baik sebelum (pretest) dan sesudah (posttest) perlakuan

\begin{tabular}{lccc}
\hline \multirow{2}{*}{ Kelompok } & \multicolumn{2}{c}{ Rerata Kadar VEGF $\left(\mathrm{pg} \mathrm{mL} \mathrm{L}^{-1}\right)$} & \multirow{2}{*}{$p^{*}$} \\
\cline { 2 - 3 } & Pretest & Posttest & \\
\hline Kelompok P0 & $43,31 \pm 5,56$ & $42,92 \pm 7,35$ & 0,877 \\
Kelompok P1 & $43,88 \pm 6,24$ & $69,80 \pm 10,04$ & $<0,001$ \\
$p^{\star *}$ & 0,814 & $<0,001$ & \\
\hline
\end{tabular}

$p^{*}=$ paired $t$ test $; p^{\star *}=$ independent $t$ test

$(p<0,001)$ (Tabel 2).

Hasil penelitian ini menunjukkan bahwa pelatihan fisik seimbang meningkatkan kadar VEGF dibandingkan dengan kontrol sedentary. Penelitian menunjukkan bahwa pelatihan fisik akut pada populasi sedentary meningkatkan mRNA VEGF otot manusia (Gavin et al. 2004). Sebaliknya, kadar protein VEGF otot rangka berkurang segera setelah latihan akut, menunjukkan bahwa VEGF dilepaskan oleh otot skeletal (Gavin et al. 2004, Kraus et al. 2004).

Pada penelitian ini, pemeriksaan kadar VEGF dilakukan pada serum, sehingga memperkuat teori bahwa VEGF ini dilepaskan dari otot ke peredaran darah tepi. Sebagai protein yang dapat disekresikan, VEGF dapat dilepaskan ke dalam sirkulasi dari berbagai organ. Penelitian menunjukkan bahwa latihan fisik dalam bentuk Nordic walking 40-50 menit/hari 3 kali/miggu selama 13 minggu dapat meningkatkan kadar VEGF serum (Izzicupo et al. 2017). Selain itu, peneliti lain menunjukkan bahwa latihan fisik dapat meningkatkan perubahan mikrovaskuler yang diinduksi oleh penuaan dan hipoperfusi yang terkait erat dengan peningkatan regulasi VEGF (Viboolvorakul dan Patumraj 2014). Peneliti lain melaporkan bahwa pelatihan fisik dapat meningkatkan aktivitas transkripsi gen VEGF pada organ otak, paru-paru dan otot skeletal yang mengindikasikan efek pelatihan fisik yang non-cell autonomous (Tang et al. 2010).

Namun berbeda dengan hasil penelitian ini, studi menggunakan pelatihan berenang submaksimal selama 12 minggu pada tikus dapat menurunkan kadar VEGF lokal pada jaringan paru-paru yang diinduksi inflamasi menggunakan nitrosamine 4(methylnitrosamino)-1-(3-pyridyl)-1-butanone (Barzegari et al. 2018). Perbedaan ini 
mengindikasikan bahwa efek protektif pelatihan fisik melalui regulasi kadar VEGF dapat dipengaruhi kodisi subjek dalam kondisi normal atau kondisi patologis, sehingga efek terhadap VEGF pun dapat berbeda.

Mekanisme yang mendasari peningkatan VEGF akibat latihan fisik tidak diketahui. Meskipun regulasi kadar VEGF oleh hypoxia-inducible factor (HIF) sudah dijelaskan dengan detail (Siswanto et al. 2017), terdapat penelitian yang membuktikan terjadinya peningkatan HIF pada latihan fisik (Lindholm dan Rundqvist 2016), dan $\mathrm{PO}_{2}$ yang menurun selama latihan, knockout HIF spesifik pada otot tidak mengganggu peningkatan VEGF spesifik pada otot (Wagner 2011). Namun belakangan ini, mekanisme molekuler yang terlibat dalam peningkatan VEGF oleh pelatihan fisik pada otak telah diidentifkasi melalui reseptor hydroxycarboxylic acid receptor 1 (HCAR1). Penelitian menunjukkan bahwa latihan fisik dan injeksi subkutan Llaktat pada mencit meningkatkan protein VEGF otak dan kepadatan kapiler pada mencit wild-type, tetapi tidak pada tikus $\mathrm{HCAR}^{-1 /}$. Reseptor HCAR1 nampaknya spesifik untuk produksi VEGF pada organ otak, karena reseptor ini tidak ditemukan pada otot (Morland et al. 2017).

Kadar vascular endothelial growth factor (VEGF) diketahui menurun seiring dengan penuaan (Zara et al. 2013, Ahluwalia et al. 2014, Hohman et al. 2015), yang menunjukkan bahwa terdapat korelasi antara VEGF dan fenotipe penuaan. Kadar VEGF yang rendah pada orang yang tua berkaitan dengan penyakit Alzheimer (Hohman et al. 2015) dan aged macular degeneration (AMD) (Luo et al. 2013). Berdasarkan hasil penelitian ini, maka pelatihan fisik seimbang dapat mencegah terjadinya penyakit penuaan seperti Alzheimer dan AMD melalui peningkatan VEGF. Namun hal ini perlu dikonfirmasi melalui penelitian lebih lanjut. Hal ini karena studi metanalisis menunjukkan bahwa pada beberapa populasi orang tua, pelatihan fisik dapat meningkatkan kadar VEGF, sedangkan pada populasi lainnya tidak memliki efek (Vital et al. 2014). Hal ini kemungkinan besar terkait dengan perbedaan populasi dan perbedaan protokol latihan sehingga untuk digunakan dalam masyarakat, protokol pelatihan harus
Tabel 3. Kadar SDF-1 pada kelompok Kontrol (P0) dan kelompok perlakuan (P1), baik sebelum (pretest) dan sesudah (posttest) perlakuan

\begin{tabular}{lccc}
\hline \multirow{2}{*}{ Kelompok } & \multicolumn{2}{c}{ Rerata Kadar SDF-1 $\left(\mathrm{ng} \mathrm{mL}^{-1}\right)$} & \multirow{2}{*}{$p^{\star}$} \\
\cline { 2 - 3 } & Pretest & Posttest & \\
\hline Kelompok P0 & $1,77 \pm 0,15$ & $1,79 \pm 0,18$ & 0,617 \\
Kelompok P1 & $1,82 \pm 0,17$ & $3,81 \pm 0,39$ & $<0,001$ \\
$p^{\star *}$ & 0,770 & $<0,001$ & \\
\hline
\end{tabular}

$p^{*}=$ paired $t$ test $; p^{* *}=$ independent $t$ test

disesuaikan sehingga dapat menghasilkan peningkatan kadar VEGF yang optimal.

Selai terkait dengan penuaan, VEGF merupakan faktor kritikal untuk pertumbuhan tuor padat, karena seiring dengan pertumbuhan masa tumor kebutuhan akan nutrisi dan oksigen memerlukan tambahan aliran vaskuler pada lingkungan sekitar tumor. Namun penelitian menunjukkan walaupun pelatihan fisik meningkatkan kadar VEGF pada mencit yang diinduksi tumor, survival rate dan pertumbuhan tmor tidak berubah (Tsai et al. 2013).

\section{Efek pelatihan fisik terhadap SDF-1}

Kadar SDF-1 diperiksa dengan menggunakan SDF-1 Elisa Kit for Rats. SDF-1 yang terkandung dalam serum darah akan terikat pada anti-rat SDF-1 monoclonal antibody yang telah dilapisi pada fase padat (sumuran). Hasil pemeriksaan kadar SDF-1 menunjukkan bahwa tidak terdapat perubahan kadar SDF-1 pada kelompok kontrol P0 $(p>0,05)$. Namun sebaliknya, kadar SDF-1 pada kelompok P1 meningkat setelah perlakuan selama 4 minggu $(p<0,001)($ Tabel 3$)$.

Hasil penelitian ini menunjukkan bahwa pelatihan fisik seimbang dapat meningkatkan kadar SDF-1 dibandingkan dengan kontrol sedentary. Hasil penelitian ini didukung oleh beberapa penelitian sebelumnya. Peneitian melaporkan bahwa kadar SDF-1 meningkat 10 menit setelah pelatihan intensitas sedang selama 30 menit pada manusia, dan kadar ini kembali ke nilai baseline 24 jam setelah pelatihan selesai (Chang et al. 2015). Sebaliknya, penelitian lain melaporkan bahwa kadar SDF-1 tidak berubah baik sesaat setelah latihan fisik, 6 jam maupun 24 jam setelah latihan fisik (Ribeiro et al. 2017). 
Pada pelatihan fisik, terjadi hipoksia seluler sementara yang menginduksi upregulasi VEGF, SDF-1 $\alpha$ dan EPO, di antara faktor-faktor angiogenik lainnya, yang dimediasi oleh HIF-1a dan nitric oxide (Nyandra et al. 2018). HIF-1a memainkan peran yang sangat penting karena mengaktifkan transkripsi VEGF, SDF-1a, dan EPO (Lenk et al. 2011, Volaklis et al. 2013); selama periode penurunan tekanan oksigen di jaringan, kadar HIF-1 $\alpha$ cenderung meningkat (Widhiantara et al. 2020), sehingga mengaktifkan SDF-1a (Ceradini et al. 2004).

Meskipun penelitian ini tidak secara khusus menyelidiki mekanisme peningkatan SDF-1 serum akibat pelatihan fisik, lingkungan mikro otot rangka iskemik yang disebabkan oleh pelatihan fisik merupakan kandidat sumber kemokin yang paling dominan (Chang et al. 2015). Sel-sel satelit otot dan fibroblast mampu mensekresi SDF-1 untuk membantu merekrut sel progenitor $\mathrm{CD}^{+} 4^{+}$ke jaringan iskemik (De Falco et al. 2004). Dengan demikian, populasi stem cells yang bersirkulasi meningkat secara signifikan setelah latihan, menunjukkan mobilisasi yang dimediasi SDF-1 dari sumsum tulang.

Penurunan kadar VEGF dan SDF-1 telah dikaitkan dengan penuaan (Zara et al. 2013, Nishiguchi et al. 2018), sebaliknya VEGF dan SDF-1 diketahui berasosiasi dengan mobilisasi stem cell endogen (Bogoslovsky et al. 2011, Tang et al. 2011, Liu et al. 2012, Herrmann et al. 2015), yang dapat digunakan sebagai strategi mencegah penuaan secara alami (Siswanto dan Pangkahila 2014).

\section{KESIMPULAN}

Berdasarkan hasil penelitian ini, dapat disimpulkan bahwa pelatihan fisik dapat meningkatkan kadar VEGF dan SDF-1. Namun korelasi antara kadar VEGF, SDF-1 dan mobilisasi stem cell endogen pada pelatihan fisik masih perlu dikaji lebih lanjut. Selain itu, perlu dilakukan penelitian lebih lanjut untuk mengidentifikasi korelasi antara peningkatan kadar VEGF dan SDF-1 dengan fenotip penuaan.

\section{UCAPAN TERIMA KASIH}

Penulis mengucapkan terimakasih kepada Universitas Dhyana Pura atas pembiayaan penelitian melalui Rencana Program dan Anggaran, Lembaga Penelitian dan Pengabdian Masyarakat (LP2M), Universitas Dhyana Pura tahun anggaran 2018 pada skema Hibah Penelitian Dasar. Ucapan terima kasih juga kami sampaikan pada semua pihak yang mendukung sehingga penelitian berjalan dengan baik.

\section{DAFTAR PUSTAKA}

Ahluwalia A, Jones MK, Szabo S, Tarnawski AS (2014) Aging impairs transcriptional regulation of vascular endothelial growth factor in human microvascular endothelial cells: implications for angiogenesis and cell survival. J Physiol Pharmacol 65: 209-215

Arsenis NC, You T, Ogawa EF, Tinsley GM, Zuo L (2017) Physical activity and telomere length: Impact of aging and potential mechanisms of action. Oncotarget 8: 45008-45019. doi: 10.18632/oncotarget.16726

Barzegari A, Mirdar S, Ranayi M (2018) Modulation of vascular endothelial growth factor and annexin A2 in response to 4-(methylnitrosamino)-1(3-pyridyl)-1-butanone -induced inflammation via swimming training. Iran J Allergy, Asthma Immunol 17: 418-427. doi: 10.18502/ijaai.v17i5.300

Bogoslovsky T, Spatz M, Chaudhry A, Maric D, Luby M, Frank J, Warach S (2011) Stromal-derived factor-1a correlates with circulating endothelial progenitor cells and with acute lesion volume in stroke patients. Stroke 42: 618-625. doi: 10.1161/STROKEAHA.110.596007

Ceradini DJ, Kulkarni AR, Callaghan MJ, Tepper OM, Bastidas N, Kleinman ME, Capla JM, Galiano RD, Levine JP, Gurtner GC (2004) Progenitor cell trafficking is regulated by hypoxic gradients through HIF-1 induction of SDF-1. Nat Med 10: 858-864. doi: 10.1038/nm1075

Chang E, Paterno J, Duscher D, Maan ZN, Chen JS, Januszyk M, Rodrigues $M$, Rennert RC, Bishop S, Whitmore AJ, Whittam AJ, Longaker MT, Gurtner GC (2015) Exercise induces stromal cellderived factor-1a-mediated release of endothelial progenitor cells with 
increased vasculogenic function. Plast Reconstr Surg 135: 340e-350e. doi: 10.1097/PRS.0000000000000917

De Falco E, Porcelli D, Torella AR, Straino S, lachininoto $M G$, Orlandi $A$, Truffa $S$, Biglioli P, Napolitano M, Capogrossi MC, Pesce M (2004) SDF-1 involvement in endothelial phenotype and ischemia-induced recruitment of bone marrow progenitor cells. Blood 104: 3472-3482. doi: 10.1182/blood2003-12-4423

Gavin TP, Robinson CB, Yeager RC, England JA, Nifong LW, Hickner RC (2004) Angiogenic growth factor response to acute systemic exercise in human skeletal muscle. J Appl Physiol 96: 19-24. doi: 10.1152/japplphysiol.00748.2003

Hayes LD, Herbert P, Sculthorpe NF, Grace FM (2017) Exercise training improves free testosterone in lifelong sedentary aging men. Endocr Connect 6: 306-310. doi: 10.1530/EC-17-0082

Herrmann M, Verrier S, Alini M (2015) Strategies to stimulate mobilization and homing of endogenous stem and progenitor cells for bone tissue repair. Front Bioeng Biotechnol 3: 79. doi: 10.3389/fbioe.2015.00079

Hill EE, Zack E, Battaglini C, Viru M, Viru A, Hackney AC (2008) Exercise and circulating cortisol levels: The intensity threshold effect. J Endocrinol Invest 31: 587-591. doi: 10.1007/BF03345606

Ho TK, Shiwen X, Abraham D, Tsui J, Baker D (2012) Stromal-cell-derived factor-1 (SDF-1)/CXCL12 as potential target of therapeutic angiogenesis in critical leg ischaemia. Cardiol Res Pract 2012: 143209. doi: 10.1155/2012/143209

Hohman TJ, Bell SP, Jefferson AL, the Alzheimer's Neuroimaging Initiative (2015) The role of vascular endothelial growth factor in neurodegeneration and cognitive decline: Exploring interactions with biomarkers of Alzheimer disease. JAMA Neurol 72: 520-529. doi: 10.1001/jamaneurol.2014.4761

Izzicupo P, D’Amico MA, Di Blasio A, Napolitano G, Di Baldassarre A, Ghinassi B (2017) Nordic walking increases circulating VEGF more than traditional walking training in postmenopause. Climacteric 20: 533-539. doi: 10.1080/13697137.2017.1366979
Kartiko BH, Siswanto FM (2018) Overtraining elevates serum protease level, increases renal p16INK4a gene expression and induces apoptosis in rat kidney. Sport Sci Health 14: 331-337. doi: $10.1007 / \mathrm{s} 11332-018-0433-6$

Kraus RM, Stallings HW, Yeager RC, Gavin TP (2004) Circulating plasma VEGF response to exercise in sedentary and endurance-trained men. J Appl Physiol 96: 1445-1450. doi: 10.1152/japplphysiol.01031.2003

Lenk K, Uhlemann M, Schuler G, Adams V (2011) Role of endothelial progenitor cells in the beneficial effects of physical exercise on atherosclerosis and coronary artery disease. J Appl Physiol 111: 321-328. doi: 10.1152/japplphysiol.01464.2010

Lindholm ME, Rundqvist H (2016) Skeletal muscle hypoxia-inducible factor- 1 and exercise. Exp Physiol 101: 28-32. doi: 10.1113/EP085318

Liu H, Liu S, Li Y, Wang X, Xue W, Ge G, Luo $X$ (2012) The Role of SDF-1CXCR4/CXCR7 axis in the therapeutic effects of hypoxia-preconditioned mesenchymal stem cells for renal ischemia/reperfusion injury. PLoS One 7: e34608. doi: 10.1371/journal.pone.0034608

Luo L, Uehara H, Zhang X, Das SK, Olsen T, Holt D, Simonis JM, Jackman K, Singh $\mathrm{N}$, Miya TR, Huang $\mathrm{W}$, Ahmed $\mathrm{F}$, Bastos-Carvalho A, Le YZ, Mamalis C, Chiodo VA, Hauswirth WW, Baffi J, Lacal PM, Orecchia A, Ferrara N, Gao $\mathrm{G}$, Young-hee $\mathrm{K}, \mathrm{Fu} \mathrm{Y}$, Owen L, Albuquerque R, Baehr W, Thomas K, Li DY, Chalam KV, Shibuya M, Grisanti S, Wilson DJ, Ambati J, Ambati BK (2013) Photoreceptor avascular privilege is shielded by soluble VEGF receptor-1. Elife 2: e00324. doi: 10.7554/eLife.00324

Morland C, Andersson KA, Haugen ØP, Hadzic A, Kleppa L, Gille A, Rinholm JE, Palibrk V, Diget EH, Kennedy LH, Stølen T, Hennestad E, Moldestad O, Cai Y, Puchades M, Offermanns S, Vervaeke $\mathrm{K}$, Bjørås $\mathrm{M}$, Wisløff $U$, Storm-Mathisen J, Bergersen LH (2017) Exercise induces cerebral VEGF and angiogenesis via the lactate receptor HCAR1. Nat Commun 8: 
15557. doi: $10.1038 /$ ncomms 15557

Nieman DC, Wentz LM (2019) The compelling link between physical activity and the body's defense system. J Sport Heal Sci 8: 201-217. doi: 10.1016/j.jshs.2018.09.009

Nishiguchi MA, Spencer CA, Leung DH, Leung TH (2018) Aging suppresses skinderived circulating SDF1 to promote fullthickness tissue regeneration. Cell Rep 24: 3383-3392.e5. doi: 10.1016/j.celrep.2018.08.054

Nyandra $M$, Kartiko $B H$, Arunngam $P$, Pangkahila A, Siswanto FM (2018) Overtraining induces oxidative stressmediated renal damage in male Wistar rats. Transylvanian Rev 26: 7659-7666. Corpus ID: 81001135

Pangkahila EA, Adiputra N, Pangkahila W, Yasa IWPS (2016) Balanced physical exercise increase physical fitness, optimize endorphin levels, and decrease malondialdehyde levels. Bali Med J 5: 493-496. doi: 10.15562/bmj.v5i3.337

Ribeiro F, Ribeiro IP, Gonçalves AC, Alves AJ, Melo E, Fernandes R, Costa R, Sarmento-Ribeiro AB, Duarte JA, Carreira IM, Witkowski S, Oliveira J (2017) Effects of resistance exercise on endothelial progenitor cell mobilization in women. Sci Rep 7: 17880. doi: 10.1038/s41598-01718156-6

Siswanto FM, Oguro A, Imaoka S (2017) Chlorogenic acid modulates hypoxia response of Hep3B cells. Person Med Universe 6: 12-16. doi: 10.1016/j.pmu.2017.03.001

Siswanto FM, Pangkahila A (2014) Pelatihan fisik seimbang meningkatkan aktivitas stem cell endogen untuk anti penuaan. Sport Fit J 2: 1-9

Siswanto FM, Pangkahila EA (2015) Pola hidup tidak teratur dan aktivitas fisik berlebih menurunkan kemampuan aktivitas seksual. Sport Fit J 3: 59-69

Tang J-M, Wang J-N, Zhang L, Zheng F, Yang J-Y, Kong X, Guo L-Y, Chen L, Huang Y-Z, Wan Y, Chen S-Y (2011) VEGF/SDF-1 promotes cardiac stem cell mobilization and myocardial repair in the infarcted heart. Cardiovasc Res 91: 402-411. doi: 10.1093/cvr/cvr053

Tang K, Xia FC, Wagner PD, Breen EC (2010) Exercise-induced VEGF transcriptional activation in brain, lung and skeletal muscle. Respir Physiol Neurobiol 170: 16-22. doi: 10.1016/j.resp.2009.10.007

Tsai M-S, Kuo M-L, Chang C-C, Wu Y-T (2013) The effects of exercise training on levels of vascular endothelial growth factor in tumor-bearing mice. Cancer Biomark 13: 307-313. doi: 10.3233/CBM-130359

Viboolvorakul S, Patumraj S (2014) Exercise training could improve age-related changes in cerebral blood flow and capillary vascularity through the upregulation of VEGF and eNOS. Biomed Res Int 2014: 230791. doi: 10.1155/2014/230791

Vital TM, Stein AM, de Melo Coelho FG, Arantes FJ, Teodorov E, SantosGalduróz RF (2014) Physical exercise and vascular endothelial growth factor (VEGF) in elderly: A systematic review. Arch Gerontol Geriatr 59: 234-239. doi: 10.1016/j.archger.2014.04.011

Volaklis KA, Tokmakidis SP, Halle M (2013) Acute and chronic effects of exercise on circulating endothelial progenitor cells in healthy and diseased patients. Clin Res Cardiol 102: 249-257. doi: 10.1007/s00392-012-0517-2

Wagner PD (2011) The critical role of VEGF in skeletal muscle angiogenesis and blood flow. Biochem Soc Trans 39: 1556-1559. doi: 10.1042/BST20110646

Widhiantara IG, Permatasari P, Rosiana IW, Sutirtayasa IWP, Siswanto FM (2020) Role of HIF-1, Siah-1 and SKN-1 in Inducing Adiposity for Caenorhabditis elegans under Hypoxic Conditions. Indones Biomed J 12: 51-56. doi: 10.18585/inabj.v12i1.1007

Zara S, Pokorski M, Cataldi A, Porzionato A, De Caro R, Antosiewicz J, Di Giulio C (2013) Development and aging are oxygen-dependent and correlate with VEGF and NOS along life span. Adv Exp Med Biol 223-228. doi: 10.1007/978-94-007-4549-0_28

Zenitalia, Pangkahila A, Pangkahila W, Siswanto FM (2018) Pelatihan fisik berlebih menurunkan jumlah hematopoietic stem cells (HSCs) dibandingkan pelatihan fisik seimbang pada tikus (Rattus norvegicus) Wistar jantan. J Biomedik 10: 16-23 